\title{
Flowering and fruit quality characteristics in some seeded and seedless pummelo cultivars
}

\author{
UMMU KALSUM $^{1,3, \vartheta}$, SLAMET SUSANTO ${ }^{1, \bullet \bullet}$, AHMAD JUNAEDI ${ }^{1}$, NURUL KHUMAIDA ${ }^{2}$, \\ HENI PURNAMAWATI \\ ${ }^{1}$ Program of Agronomy and Horticulture, Graduate School, Institut Pertanian Bogor. J1. Meranti, IPB University Darmaga, Bogor 16680, West Java, \\ Indonesia. Tel.: +62-251-8629354, Fax.: +62-251-8629352, `email: ummukalsum89@gmail.com \\ ${ }^{2}$ Program of Plant Breeding and Biotechnology, Graduate School, Institut Pertanian Bogor. Tel.: +62-251-8629354, Fax.: +62-251-8629352, Jl. Meranti, \\ Kampus IPB Darmaga, Bogor 16680, Indonesia." "email: slametsanto@gmail.com \\ ${ }^{3}$ Program of Agrotechnology, Universitas Gunadarma. Jl. Margonda Raya No. 100, Depok 16424, West Java, Indonesia.
}

Manuscript received: 5 November 2020. Revision accepted: 26 December 2020.

\begin{abstract}
Kalsum U, Susanto S, Junaedi A, Khumaida N, Purnawawati H. 2021. Flowering and fruit quality characteristics in some seeded and seedless pummelo cultivars. Biodiversitas 22: 378-385. Most of the pummelo cultivars with seeds, while other parts of it are seedless. Each cultivar is thought to have his characteristics. This study aimed to obtain more detailed information related to the difference in flowering characteristics and fruit quality of seeded and seedless pummelo cultivars. This experiment used a randomized block design with four treatments, i.e., seeded pummelo (Adas Duku and Bali Merah 1) and seedless pummelo (Bali Merah 2 and Jawa 1). The results showed an irregular pattern in the flowering and harvesting period in both the seeded and seedless groups. Adas Duku blooms twice whereas Bali Merah 1 and the two cultivars of the seedless group bloom only once a year. The highest total flower number from the four cultivars was Adas Duku and followed by Jawa 1>Bali Merah 1>Bali Merah 2. Seeded pummelo was not significant difference with seedless pummelo on several variables, except the total titrable acidity (TTA) content (seeded group > seedless group). Adas Duku became the best cultivar compared to the other three cultivars in several characteristics, such as the lowest peel thickness, the highest in the edible portion, the total soluble solids (TSS) and TTA of flesh fruit.
\end{abstract}

Keywords: Antioxidant capacity, flowering period, TSS, TTA, vitamin C

\section{INTRODUCTION}

Pummelo (Citrus maxima (Burm.) Merr) is native citrus from Southeast Asia, and it is known as the largest fruit from the citrus group (Blench 2008; Orwa et al. 2009). The native range distribution of pummelo include Bangladesh, Cambodia, Chile, India, Indonesia, Japan, Laos, Malaysia, Philippines, Thailand, and Vietnam (Orwa et al. 2009). According to the Indonesian Minister of Agriculture's Decree 511/Kpts/PD.310/9/2006, pummelo is one of the national priority developed fruit.

Pummelo fruit contained beneficial elements for health, such as antioxidant content, antihyperlipidemic, protein, calcium, etc (Orwa et al. 2009; Makynen et al. 2013). Pummelo extract has potential to be an antiglycation agent and preventing diabetic complications (Caengprasath et al 2013; Abirami et al 2014). Moreover, Schlueter and Johnston (2011) explained that vitamin $\mathrm{C}$ has a role in enzyme activation, immune function and an effective reducing agent as a powerful antioxidant. Recent findings had shown that pummelo contained various antioxidant compounds in high concentrations, therefore the fruit had potential as rich sources of natural antioxidants ( $\mathrm{Wu}$ et al. 2011; Toh et al. 2013). The antioxidant contents included total phenolic, carotenoid, vitamin $\mathrm{C}, \delta$-tocopherol, and others (Tsai et al. 2007; Makynen et al. 2013). Tsai et al. (2007) found that vitamin $\mathrm{C}$ is a powerful antioxidant and has a positive relationship with the antioxidants activity. The vitamin $\mathrm{C}$ content of pummelo fruit ranged from 38.5 to 48.2 $\mathrm{mg} / 100 \mathrm{~mL}$ of juice in Indonesia (Susanto et al. 2011) and 37.03 to $57.59 \mathrm{mg} / 100 \mathrm{~mL}$ of juice in Thailand (Pichaiyongvongdee and Haruenkit 2009).

Susanto et al. (2011) classified Indonesian pummelo into seeded and seedless cultivars. Seeded pummelo cultivars having seed more than 10 seeds per fruit, such as Cikoneng, Adas Nambangan, Adas Duku, Jawa 2, Magetan, Srinyonya, Bali Putih, Muria Merah 2, Putih Asam, and Pangkep Putih cultivars. Seedless pummelo cultivars having seed less than 10 seeds per fruit, such as Bageng, Jawa 1, Bali Merah 2, Muria Merah 1, and Giri Matang. Seeded and seedless pummelo is thought to have different characteristics, especially flowering characteristics, fruiting, harvest time, and fruit quality. The continuity of fruit supply in the market depends on the flowering and harvest periods of pummelo cultivars

Previous research reported the differences in flowering periods, characteristics of flower and fruit occurring in several cultivars planted in the same environment, such as in the persimmon (da Silva et al. 2016), three citrus species (Sharma et al. 2017), peach (Alves et al. 2018). Pummelo in Magetan region generally bloomed from October to November. Harvest period occurred from May to June in Magetan, while in Pati, Kudus, and Bireun from January to Februari (Susanto et al. 2016). The main harvest of pummelo occurs only once a year (Rahayu 2012). Current information does not explain the flowering characteristics of seeded and 
seedless pummelo in more details. This study aimed to obtain more detailed information related to the difference in flowering characteristics and fruit quality of seeded and seedless pummelo cultivars.

\section{MATERIALS AND METHODS}

\section{Study area}

This research was conducted from October 2018 to September 2019 at the pummelo production center, i.e., Tambakmas Village, Sukomoro District, Magetan Regency. The 5-6 years old of pummelo trees was the object of this research. This experiment used a randomized block design with 1 factor, i.e., cultivar. The cultivars were seeded pummelo (Adas Duku and Bali Merah 1) and seedless pummelo (Bali Merah 2 and Jawa 1). Fruit quality analysis was carried out in the Postharvest Laboratory of the Department of Agronomy and Horticulture, IPB. Analysis of antioxidant capacity was carried out at the Indonesian Spice and Medicinal Crops Research Institute, Bogor.

\section{Procedures}

One experimental unit consist of ten secondary branches from one plant, replicated 5 times. Plant material used 5 plants per cultivar, and thus 20 plants in total for 4 cultivars. Each observed branch was arranged with 50 - 60 leaves per fruit. The fruits were bagged at four weeks after anthesis (WAA) using transparent plastic to protect from pest attacks. The observed variables were flowering and harvesting periods, fruit weight, fruit diameter, peel thickness, seed number, edible portions, total soluble solids (TSS), total titrable acidity (TTA), TSS/TTA ratio, vitamin C, and IC50. TSS was measured using a PAL-1 ATAGO Digital Pocket Refractometer. TTA, and vitamin $\mathrm{C}$ using the titration method. TTA was titrated using $\mathrm{NaOH}$ with a solution of phenolphthalein (PP) indicator (AOAC 2000), while vitamin $\mathrm{C}$ was analyzed using iodine titration (Ciancaglini et al. 2001) with modification. IC50 was analyzed using 2.2diphenyl-1-picrylhydrazyl (DPPH) (Makynen et al. 2013).

\section{Data analysis}

The experimental data were analyzed using an analysis of variance $(\alpha=0.05)$. If the analysis of variance shows significantly different results, it would be continued with the Honestly Significant Difference (Tukey) test $(\alpha=0.05)$. Data were calculated by SAS software.

\section{RESULTS AND DISCUSSION}

\section{Flowering and harvest period of seeded and seedless pummelo}

Flowering periods between the seeded and seedless groups are different. Each cultivar from the two groups has its pattern. Although Adas Duku and Bali Merah 1 belong to one group (seeded pummelo), the flowering period of both cultivars did not occur in the same period. Adas Duku bloomed twice a year while Bali Merah 1 bloomed only once. The two members of the seedless group (Bali Merah 2 and Jawa 1) bloomed only once a year, but the flowering periods of them occur at different periods. Flowering periods and flower numbers of each cultivar are shown in Figure 1.

The first flowering periods of Adas Duku occurred in the $4^{\text {th }}$ week of November until the 3rd week of December 2018 while the second period happened in the 1st week until the $3^{\text {rd }}$ week of February 2019. Bali Merah 1 and Bali Merah 2 were flowering in similar periods, i.e., the $4^{\text {th }}$ week of November 2018 until the 2nd week of December 2018. While Jawa 1 has a long flowering period, in the $4^{\text {th }}$ week of October until the $2^{\text {nd }}$ week of December 2018. The majority of the flowering period from four cultivars occurred in November. This is a phenomenon similar to that stated by Susanto et al. (2016) that the flowering of pummelo in Magetan happened from October until November. Besides, the flowering period of pummelo in Tambakmas village occurred after entering the rainy season. The flowering period of Indonesian pummelo is almost the same time as some countries, i.e. Thailand, Nepal, Vietnam and India (Orwa et al 2009; Sawant and Panhekar 2017).

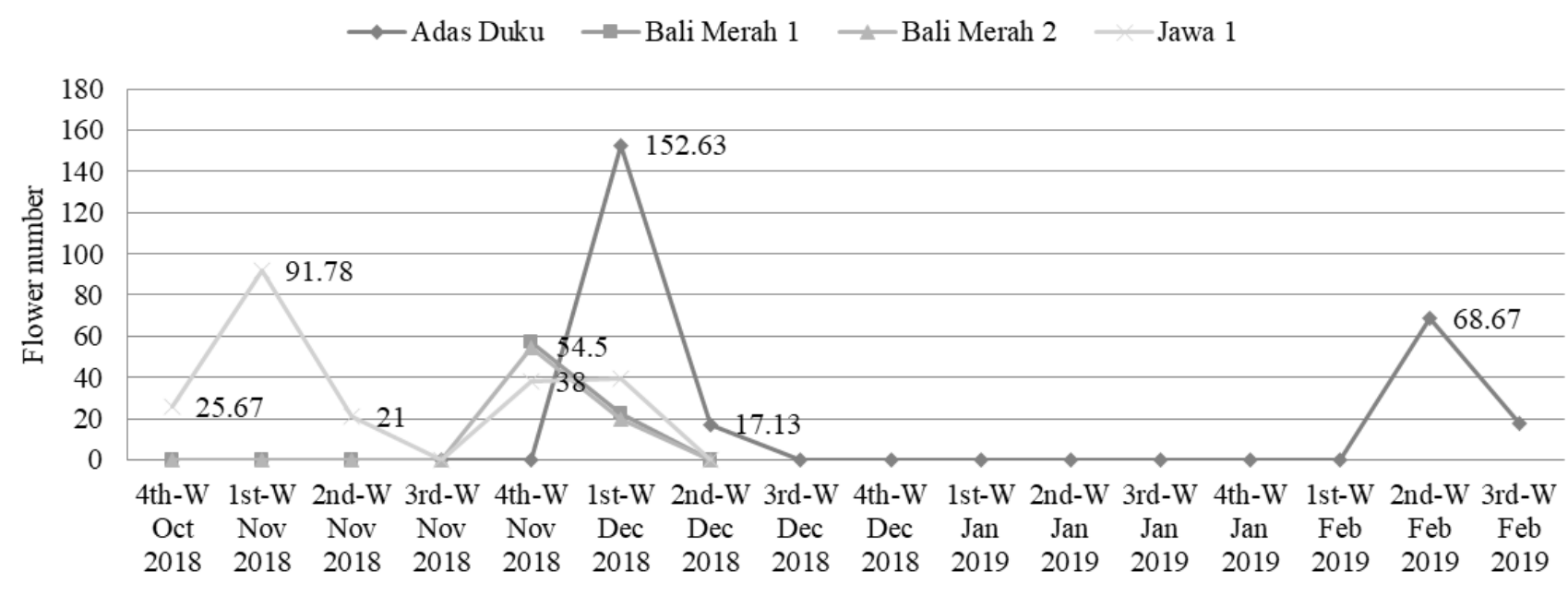

Figure 1. The flowering period of four pummelo cultivars. W: week 
Table 1. Flowering and the harvest period of seeded and seedless pummelo

\begin{tabular}{|c|c|c|c|c|}
\hline Cultivars & Flower period & $\begin{array}{l}\text { Flower number } \\
\text { (in } 10 \text { branches) }\end{array}$ & Harvest period & $\begin{array}{c}\text { Harvest time } \\
\text { (days after } \\
\text { anthesis) }\end{array}$ \\
\hline \multicolumn{5}{|l|}{ Group } \\
\hline Seeded & $\begin{array}{l}4^{\text {th }} \text { week of November }-3^{\text {rd }} \text { week of } \\
\text { December } 2018 \text { and } 1^{\text {st }} \text { week }-3^{\text {rd }} \text { week } \\
\text { of February } 2019\end{array}$ & 117.80 & $\begin{array}{l}2^{\text {nd }} \text { week of May }-1^{\text {st }} \text { week of June } 2019 \\
\text { and } 4^{\text {th }} \text { week of July }-1^{\text {st }} \text { week of August } \\
2019\end{array}$ & 169.67 \\
\hline Seedless & $\begin{array}{l}4^{\text {th }} \text { week of October }-2^{\text {nd }} \text { week of } \\
\text { December } 2018\end{array}$ & 144.88 & $3^{\text {rd }}$ week of April $-4^{\text {th }}$ week of May 2019 & 167.67 \\
\hline \multicolumn{5}{|l|}{ Seeded } \\
\hline $\begin{array}{l}\text { Adas Duku } \\
\left(1^{\text {st }} \text { period }\right)\end{array}$ & $\begin{array}{l}4^{\text {th }} \text { week of November }-3^{\text {rd }} \text { week of } \\
\text { December } 2018\end{array}$ & & $\begin{array}{l}2^{\text {nd }} \text { week of May - } 1^{\text {st }} \text { week of June } 2019 \\
4^{\text {th }} \text { week of July }-1^{\text {st }} \text { week of August } 2019\end{array}$ & $\begin{array}{l}170.39 \mathrm{bc} \\
168.29 \mathrm{~b}\end{array}$ \\
\hline ( $2^{\text {nd }}$ period) & $1^{\text {st }}$ week - $3^{\text {rd }}$ week of February 2019 & $86.67 \mathrm{a}$ & & \\
\hline Bali Merah 1 & $\begin{array}{l}4^{\text {th }} \text { week of November }-2^{\text {nd }} \text { week of } \\
\text { December } 2018\end{array}$ & $79.67 \mathrm{a}$ & $2^{\text {nd }}$ week $-4^{\text {th }}$ week of May 2019 & $170.78 \mathrm{c}$ \\
\hline \multicolumn{5}{|l|}{ Seedless } \\
\hline Bali Merah 2 & $\begin{array}{l}4^{\text {th }} \text { week of November }-2^{\text {nd }} \text { week of } \\
\text { December } 2018\end{array}$ & $74.00 \mathrm{a}$ & $2^{\text {nd }}$ week $-4^{\text {th }}$ week of May 2019 & $170.24 \mathrm{~b}$ \\
\hline Jawa 1 & $\begin{array}{l}4^{\text {th }} \text { week of October until } 2^{\text {nd }} \text { week of } \\
\text { December } 2018\end{array}$ & $215.75 \mathrm{c}$ & $3^{\text {rd }}$ week of April until $3^{\text {rd }}$ May 2019 & $165.37 \mathrm{a}$ \\
\hline
\end{tabular}

Note: In each column, values followed by the same letter are not significantly different at Tukey test $\alpha=0.05$.

The flower number of the seeded group did not show any difference with the seedless group, but the circumstances between cultivars in the group revealed variations in the flower number (Table 1). The flower number of Adas Duku was higher different from Bali Merah 1 in the seeded group, while in the seedless group the flower number from Bali Merah 2 was lesser than Jawa 1. The four cultivars showed a varying number of flowers on each flowering period. When compared among cultivars, it showed that of the 10 selected branches, the highest flower number was Adas Duku (total flowers in the two periods) followed by Jawa 1 then Bali Merah 1, and Bali Merah 2. The flower number of Adas Duku in the first period were higher than the second period. Jawa 1 had a long flowering period with the highest flower number that occurred in early November, after that the flower number that appears is only a small amount (19.5 - 39.5 flowers). Bali Merah 1, and Bali Merah 2 have the least amount of flowers, i.e. 79.67 and 74 flowers, respectively. Various flowering periods and the flower number may be occurred due to the differences of the genetic factors in each cultivar. Cortés-Rojas et al (2016) represented that the crop produced large flowers and high yield depends on cultivars, tree age, and environmental conditions. Moreover, Amiri et al. (2016) explained that climatic condition and management systems have great effect on the flower number of citrus.

The information about flowering periods can be used to predict harvest time. Differences in flowering period resulted in different harvest time (Table 1). In the seeded group, the fruit of the two cultivars can be harvested in May 2019 ( $2^{\text {nd }}$ week $-4^{\text {th }}$ week of May) after that only the Adas Duku could be harvested, i.e., in $1^{\text {st }}$ week of June 2019 and $4^{\text {th }}$ week of July - $1^{\text {st }}$ week of August 2019. In the seedless group, the fruit harvesting occurred earlier than the seeded group, that is for Jawa 1 (in the $3^{\text {rd }}$ week of April 2019).
Another harvest period of the seedless group occurred in May 2019 for both, i.e., Bali Merah $2\left(2^{\text {nd }}\right.$ week - $4^{\text {th }}$ week of May) and Jawa 1 ( $1^{\text {st }}$ week $-3^{\text {rd }}$ week of May). The information about harvest periods is expected to be a reference for farmers about the availability of pummelo fruit.

Seeded pummelo has relatively the same harvest time as the seedless pummelo, i.e. 169.67 and 167.67 days, respectively. Harvest time in the seeded group, between two members is harvested in a time range that is not much different (it's about 170 days) but the harvest time of Adas Duku in the second period is shorter (168.29 days) than the other harvest time. The second period of harvesting of Adas Duku occurs in a different season (i.e. dry season) with other harvesting time. In the seedless group, Bali Merah 2 was harvested longer than Jawa 1. Harvest time for the four cultivars showed that Jawa 1 (165.37 days) could be harvested earlier than the other three cultivars. The longest harvest time was found for cultivar Bali Merah 1 (170.78 days). The determining of optimum harvest was affected by environment, i.e the weather during start flowering until harvest time (Blažek and Pištěková 2017). The optimum harvest time is basically needed to produce the desired fruit quality. The tree age and fruit age affected fruit development and fruit quality, such as pummelo ( $\mathrm{Na}$ Nakorn and Chalumpak 2016; Preecha and Na Nakorn 2018) and sweet orange (Deep et al. 2019). Fruits can be harvested when they meet the minimum criteria, such as the standards set by the UNECE Codex (2017) in which pummelo must have a minimum fruit diameter of $10 \mathrm{~cm}$ and a TSS of $8^{\circ}$ Brix. Each cultivar generally has a different harvest time, such as mango (Ahmed and Ahmed 2014), and cherry (Overbeck et al. 2017). 


\section{Fruit weight and fruit diameter of seeded and seedless pummelo}

Fruit weight and fruit diameter (transverse and longitudinal) were observed at harvest (Table 2). Fruit weight was not significantly different between the two groups (seeded and seedless pummelo) and among members of their groups. The fruit weights of four cultivars was approximately $1 \mathrm{~kg}$. The ideal standard from the Codex Alimentarius Commission (2011) about the fruit weight of pummelo was more than $400 \mathrm{~g}$ and the fruit weight of the four cultivars is categorized in code size 5 (900 - $1100 \mathrm{~g})$. Thus, the four cultivar have good commercial acceptance in terms of their fruit weight.

The transverse diameter did not show differences result between the two groups (seeded and seedless) as well as among members within the seeded group. Moreover, a difference in transverse diameter was seen between the two members of the seedless group, which is Jawa 1 is higher $(11.28 \%)$ than Bali Merah 2. When it was compared among cultivars, the Jawa 1 was also the largest size in transverse fruit diameter then followed by the two cultivars of the seeded group (Bali Merah 1 and Adas Duku) and the smallest transverse diameter was Bali Merah $2(11.79 \mathrm{~cm})$.

The longitudinal diameter of pummelo fruit did not indicate a difference, either between the two groups, within groups or among cultivars. The longitudinal diameter of the four cultivars ranged from 11.59 to $11.93 \mathrm{~cm}$. The fruit diameter (transverse and longitudinal diameter) of the four cultivars had exceeded the minimum standard set by the Codex UNECE standard (2017) that the fruit diameter should be at least $10 \mathrm{~cm}$.

\section{Peel thickness, seed number and edible portions of seeded and seedless pummelo}

Fruit peel thickness, seeds number, and edible portions of the four cultivars are presented in Table 3 . The fruit peel thickness of seeded pummelo was not different as compared with seedless ones. There is a variation in the fruit peel thickness between the members in the seeded group but the peel thickness of each member in the seedless group is almost the same size. Furthermore, a difference in fruit peel thickness was seen among cultivars. Bali Merah 1 is the highest peel thickness $(1.83 \mathrm{~cm})$ and it is significantly higher than the three other cultivars. The lowest peel thickness among cultivars was Adas Duku $(1.45 \mathrm{~cm})$. Fruit peel was hard in the early stages of fruit development and will soften at the maturity stage. The characteristic of fruit peel become the important parameter in the fruit durability. Orwa et al. (2009) explained that pummelo is a fruit with thick peel due to its long shelf life periods. Thus, the cultivars with the thick fruit peel can be stored for a longer time than the cultivars with thin fruit peel.

The grouping of seeded and seedless fruits is seen from the seed number in each fruit. The average seed number of the seeded group was 47.33 , while the seedless group has an average number of 6.38 seeds. The seed number within the seeded group does not show a difference (Adas Duku = 48.17 seeds, Bali Merah $1=45.67$ seeds) while members of the seedless group had seed numbers less than 10 seeds (Bali Merah $2=5.67$ seeds, Jawa $1=6.80$ seeds). According to
Susanto et al., (2011) that the pummelo fruit is categorized as a seedless group if the seed number per fruit $<10$, while the fruits that have $>10$ seeds per fruit are the seeded group.

The edible portion of seeded pummelo did not show a difference with seedless pummelo. Among cultivars in the group, there was diversity as shown by Adas Duku which had an edible portion was higher than Bali Merah 1 even though they were in the same group (seeded group). In the comparison among cultivars, there was a difference of edible portion, such as Adas Duku which had the highest edible portion and is not much different from the edible portion of Bali Merah 2. However, the edible portion of Adas Duku is different from the other two cultivars. The edible portion of all cultivars is more than $50 \%$. The highest edible portion of Adas Duku is thought to occur due to the smallest peel thickness among the four cultivars. In contrast, Bali Merah 1 was the lowest edible portion caused by the highest peel thickness. Rahayu (2012) reported that edible portions of pummelo were related to fruit peel thickness, peel weight, and seed weight.

Table 2. Fruit weight and diameter of seeded and seedless pummelo

\begin{tabular}{lccc}
\hline $\begin{array}{c}\text { Cultivars / } \\
\text { fruit group }\end{array}$ & $\begin{array}{c}\text { Fruit } \\
\text { weight } \\
\text { (g) }\end{array}$ & $\begin{array}{c}\text { Transverse } \\
\text { diameter } \\
(\mathbf{c m})\end{array}$ & $\begin{array}{c}\text { Longitudinal } \\
\text { diameter }(\mathbf{c m})\end{array}$ \\
\hline Group & & & \\
$\quad$ Seeded & 1056.13 & 12.23 & 11.86 \\
$\quad$ Seedless & 994.27 & 12.61 & 11.71 \\
Seeded & & & \\
$\quad$ Adas Duku & 1027.50 & $11.95 \mathrm{a}$ & 11.76 \\
$\quad$ Bali Merah 1 & 1088.86 & $12.69 \mathrm{ab}$ & 11.93 \\
Seedless & & & \\
$\quad$ Bali Merah 2 & 968.60 & $11.79 \mathrm{a}$ & 11.59 \\
Jawa 1 & 1015.67 & $13.12 \mathrm{~b}$ & 11.77 \\
\hline
\end{tabular}

Note: In each column, values followed by the same letter are not significantly different at Tukey test $\alpha=0.05$.

Table 3. Peel thickness, seed number and edible portions of fruit from four cultivars

\begin{tabular}{lccc}
\hline $\begin{array}{c}\text { Cultivars/fruit } \\
\text { group }\end{array}$ & $\begin{array}{c}\text { Peel thickness } \\
(\mathbf{c m})\end{array}$ & $\begin{array}{c}\text { Seed } \\
\text { number }\end{array}$ & $\begin{array}{c}\text { Edible } \\
\text { portions (\%) }\end{array}$ \\
\hline Group & & & \\
$\quad$ Seeded & 1.65 & $47.33 \mathrm{~b}$ & 57.47 \\
$\quad$ Seedless & 1.64 & $6.38 \mathrm{a}$ & 52.46 \\
Seeded & & & \\
$\quad$ Adas Duku & $1.45 \mathrm{a}$ & $48.17 \mathrm{~b}$ & 59.92 \\
$\quad$ Bali Merah 1 & $1.83 \mathrm{~b}$ & $45.67 \mathrm{~b}$ & 50.11 \\
Seedless & & & \\
$\quad$ Bali Merah 2 & $1.69 \mathrm{a}$ & $5.67 \mathrm{a}$ & 54.49 \\
Jawa 1 & $1.58 \mathrm{a}$ & $6.80 \mathrm{a}$ & 50.43 \\
\hline
\end{tabular}

Note: In each column, values followed by the same letter are not significantly different at Tukey test $\alpha=0.05$. 
Table 4. The total soluble solids (TSS) and total titrable acidity (TTA) quality of seeded and seedless pummelo juice

\begin{tabular}{lllc}
\hline $\begin{array}{c}\text { Cultivar / fruit } \\
\text { group }\end{array}$ & \multicolumn{1}{c}{$\begin{array}{c}\text { TSS } \\
\left({ }^{\circ} \text { Brix }\right)\end{array}$} & $\begin{array}{c}\text { TTA } \\
(\boldsymbol{\%})\end{array}$ & $\begin{array}{c}\text { TSS/TTA } \\
\text { ratio }\end{array}$ \\
\hline $\begin{array}{llll}\text { Group } \\
\quad \text { Seeded }\end{array}$ & 9.36 & $1.11 \mathrm{q}$ & 12.24 \\
$\quad$ Seedless & 9.45 & $0.82 \mathrm{p}$ & 13.97 \\
Seeded & & & \\
$\quad$ Adas Duku & $11.02 \mathrm{~b}$ & $1.46 \mathrm{c}$ & $8.24 \mathrm{a}$ \\
$\quad$ Bali Merah 1 & $8.50 \mathrm{a}$ & $0.47 \mathrm{a}$ & $15.99 \mathrm{c}$ \\
Seedless & & & \\
$\quad$ Bali Merah 2 & $8.44 \mathrm{a}$ & $0.43 \mathrm{a}$ & $17.69 \mathrm{c}$ \\
Jawa 1 & $10.96 \mathrm{~b}$ & $1.14 \mathrm{~b}$ & $10.46 \mathrm{~b}$ \\
\hline
\end{tabular}

Note: In each column, values followed by the same letter are not significantly different at Tukey test $\alpha=0.05$. TSS: total soluble solids; TTA: total titrable acidity.

\section{The total soluble solids (TSS) and total titrable acidity (TTA) content of seeded and seedless pummelo juice}

Some characteristics that describe the internal quality of pummelo juice are total soluble solids (TSS), total titrable acidity (TTA), and TSS/TTA ratio (Table 4). Seeded pummelo had similar TSS with seedless pummelo that is 9.36 and $9.45{ }^{\circ}$ Brix, respectively. TSS diversity among members in the same group was seen in both groups, such in the seeded group expressed that Adas Duku > Bali Merah 1 with a difference in value is 2.52. A similar result was also found for the seedless group, Jawa $1>$ Bali Merah 2 (a difference in value 2.52). As compared among cultivars expressed a variation in TSS. The highest TSS among the four cultivars was Adas Duku (11.02 ${ }^{\circ}$ Brix), while the lowest TSS was Bali Merah $2\left(8.44^{\circ}\right.$ Brix $)$. The lowest TSS content in this research meets the minimum fruit maturity standard based on the Codex UNECE standard (2017), i.e., $8^{\circ}$ Brix

The total titrable acidity (TTA) content of the seeded group was higher than the seedless group. The TTA content from each member of the seeded group is not always higher than the TTA content of every member of the seedless group. In the seeded group, Adas Duku has high TTA content but Bali Merah 1 expressed a lower TTA content than Jawa 1 which is a cultivar of the seedless group. The TTA content of four pummelo cultivars ranged from 0.43 to $1.46 \%$. The highest of TTA content was Adas Duku, followed by Jawa 1 . The TTA content of Bali Merah 1 has a no different result with Bali Merah 2, whereas both of them have a TTA content that is lower than two other cultivars. The TTA content of Bali Merah 1 and Bali Merah 2 is only half of the TTA content of the two other cultivars. These findings are consistent with the values of TTA content found in some seeded pummelo in some countries (Fikrinda et al. 2015; Wangchu et al. 2017). The TTA content of pummelo genotypes ranged from 0.32 to $1.63 \%$ (Wangchu et al. 2017; Nandi et al. 2019). Fattahi et al. (2011) reported that the TTA increased gradually but the decreased at the full ripe stage.

The seeded group had a similar TSS/TTA ratio as compared to the seedless group. Although the two groups did not show any differences, the TSS/TTA ratio among members in the groups had a diversity of values. Results of the seeded group have shown that Adas Duku has a lower
TSS/TTA ratio than Bali Merah 1, meanwhile in seedless group revealed that Bali Merah 2 is greater different to Jawa 1. The TSS/TTA ratio of the four cultivars showed different results with the range 8.24 to 17.79 . The TSS/TTA ratio meets the minimum fruit maturity standard. The highest TSS/TTA ratio was Bali Merah 2, and it is not different from Bali Merah 1, i.e., > 10. Bali Merah 1 and Bali Merah 2 are grouped into good quality, whereas Adas Duku and Jawa 1 are categorized into minimum maturity. This refers to Ladaniya (2008) explained that the TSS/TTA ratio of citrus between 8 to 10 is an acceptance ratio as minimum maturity, while the ratio 10 to 16 is a good quality of acceptance ratio.

The TSS, TTA content, and TSS/TTA ratio of flesh fruit from Bali Merah 1 looks similar to Bali Merah 2. Genetic similarities of the two cultivars probably cause this. Previous research of Rahayu (2012) showed that Bali Merah 1 and Bali Merah 2 cultivars have a high percentage of similarity (76.1\%) based on morphological and isoenzyme markers. Furthermore, Wangchu et al. (2017) TSS and TTA had strong positive and significant correlation with genetic factor (included heritability).

\section{Vitamin $\mathrm{C}$ and antioxidant capacity of seeded and seedless pummelo}

Vitamin C content of seeded pummelo did not show any differences from the seedless pummelo, i.e., 76.71 and 77.37 $\mathrm{mg} / 100 \mathrm{~mL}$ of juice respectively. In the seeded group, vitamin C of Bali Merah 1 is higher (it is about 13\%) than Adas Duku. Besides, vitamin C contained in members of the seedless group had the content value that does not differ much. The vitamin $\mathrm{C}$ content differed among cultivars as shown in Figure 2. Adas Duku has the lowest vitamin C content and then followed by Bali Merah 2, whereas the highest vitamin $\mathrm{C}$ content was Bali Merah 1. The variation in vitamin $\mathrm{C}$ content among cultivars might be due to genetic factors, as was the case for the 24 pummelo accession in Assam, India (Bharali et al. 2017). The vitamin C content in each fruit can be different due to the environment and its cultivation practices. Musyarofah et al. (2020) reported that vitamin $\mathrm{C}$ content can affected by altitude and intensive cultural practices.

Vitamin $\mathrm{C}$ content from the four cultivars ranged from 72.44 to $82.56 \mathrm{mg} / 100 \mathrm{~mL}$ of juice. The vitamin $\mathrm{C}$ content from $100 \mathrm{~mL}$ of pummelo juice is already close to the daily recommended intake of vitamin C. Karger (2015) represented that an average requirement of the vitamin $\mathrm{C}$ intake is $110 \mathrm{mg} /$ day and $95 \mathrm{mg} /$ day for adult men and woman, respectively. These values represent the revised reference values for vitamin $\mathrm{C}$, which are higher than the previous reference $(90 \mathrm{mg}$ for adults men and $75 \mathrm{mg}$ for adults woman). Based on the information, then we need to drink $150 \mathrm{~mL}$ of pummelo juice or $15 \mathrm{~g}$ flesh fruit every day to meet the daily vitamin $\mathrm{C}$ intake.

Vitamin $\mathrm{C}$ from red flesh pummelo scavenging different forms of free radicals was $20 \%$, including DPPH, superoxide anion, and hydrogen peroxide radicals (Tsai et al. 2007). DPPH (2,2-diphenyl-1-picrylhydrazyl) assay used to evaluate the antioxidant activity of the extract prepared in nhexane extract by measuring the scavenging capacity of DPPH present in the tested solvent extract. Khan et al. 
(2018) represented that the DPPH scavenging assay was an antioxidant method conducted commonly due to their highly selectivity compared to other antioxidant test.

IC50 was the effective concentration value seen in extract concentrations that can inhibit $50 \%$ oxidation for DPPH scavenging. Tsai et al (2007) reported that DPPH is a stable free radical widely used as a model system to investigate the scavenging activity of natural compounds. IC50 from four cultivars are shown in Figure 3.

IC50 of seeded pummelo did not show any different with seedless pummelo, it indicated that the antioxidant capacity of seeded pummelo was similar to seedless pummelo. There was no different in IC50 between members in the two groups nor among cultivars. The IC50 value of four cultivars revealed ranges from 8.82 to $12.65 \%$. Some findings from previous research showed that antioxidant capacity would be inversely proportional to IC50. The lower IC50 value has a higher antioxidant capacity (Fattahi et al. 2011). Thus, the cultivar with the lowest IC50 (Adas Duku $=8.82$ ) indicated that the highest antioxidant capacity.

The free radical scavenging ability of juice could be attributed to vitamin $\mathrm{C}$ because it is a natural bioactive substance that acts as a powerful antioxidant compound (Tsai et al. 2007). Furthermore, Jayaprakasha et al. (2008) reported that vitamin $\mathrm{C}$ is one of the major components for antioxidant activity in edible plants so it is necessary to extract the compound effectively when antioxidants activities are measured. Tsai et al. (2007) classified vitamin $\mathrm{C}$ as a rapid level of radical scavenging. It was tested on the basis of DPPH kinetic, superoxide anion kinetic, and hydrogen peroxide kinetic methods.
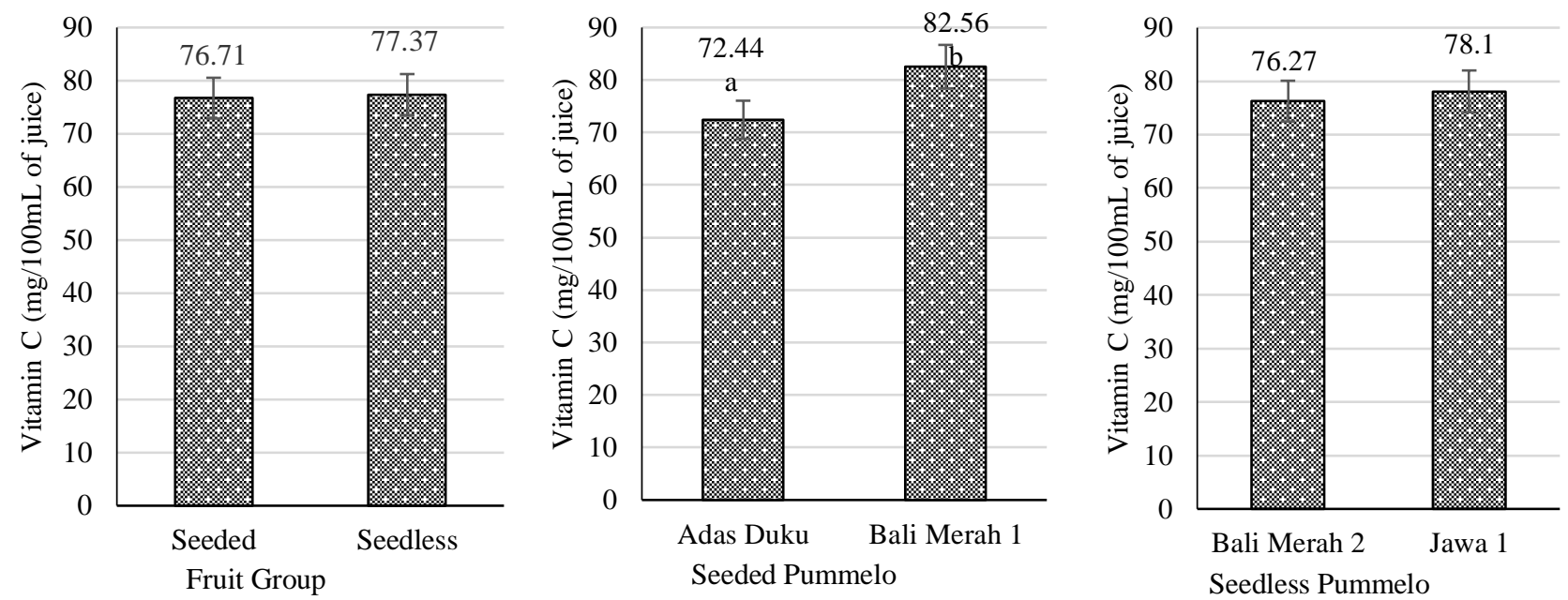

Figure 2. Vitamin $\mathrm{C}$ of four pummelo cultivar (values followed by the same letter are not significantly different at Tukey test $\alpha=0.05$ )
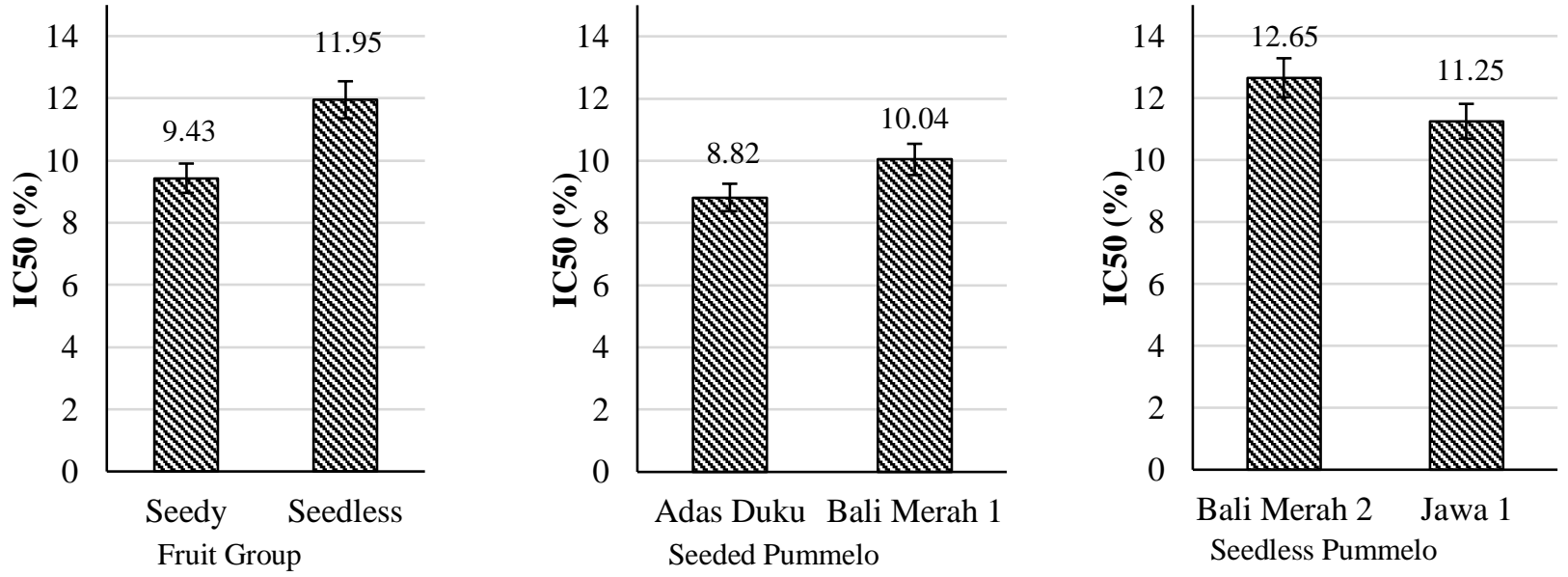

Figure 3. Antioxidant capacity of seeded and seedless pummelo 
In conclusion, each cultivar in a group (seeded or seedless pummelo) showed a different pattern in flowering and harvest periods. Adas Duku bloomed twice a year while Bali Merah 1 and the two cultivars of the seedless group only once. The first blooming periods of Adas Duku occurred in late November until the $3^{\text {rd }}$ week of December 2018, while the second periods occurred in $1^{\text {st }}$ week and $3^{\text {rd }}$ week of February 2019. The harvest periods of Adas Duku occurred from the $2^{\text {nd }}$ week of May until $1^{\text {st }}$ week of June and 4th week of July until 1st week of August 2019. Jawa 1 cultivars flowered in late October 2018 until the $2^{\text {nd }}$ week of December 2018, and the harvest periods occurred in the $3^{\text {rd }}$ week of April until the $3^{\text {rd }}$ week of May 2019. Bali Merah 1 and Bali Merah 2 simultaneously bloomed on the $4^{\text {th }}$ week of November 2018 until the $2^{\text {nd }}$ week of December and harvested from 2nd week until the $4^{\text {th }}$ week of May 2019. The flower number of each cultivar in a group is also different. Flower number of Adas Duku in the first period higher than the second period. The highest flower number from the four cultivars was found for Adas Duku, followed by Jawa $1>$ Bali Merah 1>Bali Merah 2. Seeded pummelo was not significantdifferences with seedless pummelo in several variables, except the TTA content (seeded group > seedless group). The variables that were not difference among cultivars were fruit weight, longitudinal diameter, and IC50. Adas Duku became the best cultivar compared to the other three cultivars in several characteristics, such as the lowest peel thickness, the highest in the edible portion, TSS and TTA of flesh fruit.

\section{ACKNOWLEDGEMENTS}

Thank you to the Ministry of Research Technology and Higher Education for providing domestic postgraduate scholarship programs in 2017.

\section{REFERENCES}

Abirami A, Nagarani G, Siddhuraju P. 2014. In vitro antioxidant, antidiabetic, cholinesterase and tyrosinase inhibitory potential of fresh juice from Citrus hystrix and C. maxima fruits. Food Sci Hum Well 31: 16-25. DOI: 10.1016/j.fshw.2014.02.001.

Ahmed OK, Ahmed SET. 2014. Determination of optimum maturity index of mango fruits (Mangifera indica L.) in Darfur. Agric Biol J N Am 5 (2): 97-103.

Alves G, Gelain J, Vidal GS, Nesi CN, De Mio LLM, Biasi LA. 2018 Flowering period and fruit quality of peach trees selections and cultivars in the metropolitan region of Curitiba. Revista Brasileira de Fruticultura 40 (3): 1-10. DOI: 10.1590/0100-29452018991

Amiri NA, Kangarshahi AA, Reykande JM. 2016. Investigation of flower and fruit set in some citrus varieties in east of Mazandaran climate. Iranian J Hortic Sci 47 (2): 257-264.

AOAC. 2000. AOAC Official Method 942.15 Acidity (Titrable) of Fruit Products. AOAC, Washington DC., USA.

Bharali R, Bhattacharyya RK, Das P. 2017. Bioactive compounds and total antioxidant activity of pummelo (Citrus grandis L.) ecotypes of Assam. Bull Environ Pharm Life Sci 6 (1): 342-347.

Blažek J, Pištěková I. 2017. Prediction of the harvesting time for four apple cultivars on the basis of beginning of flowering and attaining of T-stage of fruitlet and dependence of diameter of fruitlets at $\mathrm{T}$-stage and fruit at ripening stage. J Hortic Res 25 (1): 55-59. DOI: 10.1515/johr-20170006 .
Blench R. 2008. A History of Fruit on The Southeast Asian Mainland. Research Institute for Humanity and Nature, Japan.

Caengprasath N, Ngamukote S, Makynen K, Adisakwattana S. 2013. The protective effects of pomelo extract (Citrus grandis L. Osbeck) against fructose-mediated protein oxidation and glycation. EXCLI J 12: 491 502.

Ciancaglini P, Santos HL, Daghastanli KRP, Thedei GJr. 2001. Using a classical method of vitamin $\mathrm{C}$ quantification as a tool for discussion of its role in the body. Biochem Mol Biol Edu 29: 110-114.

Codex Alimentarius. 2011. Standard for Pummelos: CXS 214-1999. FAO/WHO International Food Standards. FAO, Rome \& WHO, Geneva.

Cortés-Rojas ME, Mesa-Torres PA, Grijalba-Rativa CM, Pérez-Trujillo MM. 2016. Yield and fruit quality of the blueberry cultivars Biloxi and Sharpblue in Guasca, Colombia. Agronomía Colombiana 34 (1): 33 41. DOI: 10.15446/agron.colomb.v34n1.54897.

da Silva MJC, Ferreira TE, Domiciano S, Paiva APM, Tecchio MA, Leonel S. 2016. Phenology, yield and fruit quality of four persimmon (Diospyros kaki L.) cultivars in São Paulo's Midwest countryside, Brazil. Afr J Agric Res 11 (52): 5171-5177. DOI: 10.5897/AJAR2016.11670

Deep A, Tinna D, Gandhi N. 2019. Effect of plant age and ripening stages on physical characteristics of sweet orange cv. Malta. J Pharmacog Phytochem SP4: 17-19.

Fattahi J, Hamidoghli Y, Fotouhi R, Ghasemnejad M, Bakhshi D. 2011. Assessment of fruit quality and antioxidant activity of three citrus species during ripening. South West J Hortic Biol Environ 2 (2): 113128.

Fikrinda W, Susanto S, Efendi D, Melati M. 2015. Study on fruit quality of selected seeded pummelo cultivars and its relationship with antioxidant activity content during storage period. Agrivita 37 (3): 210-219. DOI: 10.17503/Agrivita-2015-37-3-p210-219.

Jayaprakasha GK, Girennavar B, Patil BS. 2008. Antioxidant capacity of pummelo and navel oranges: Extraction efficiency of solvents in sequence. LWT 41: 376-384. DOI: 10.1016/j.1wt.2007.03.017.

Karger S. 2015. New Reference values for vitamin C intake: German Nutrition Society (DGE). Ann Nutr Metab 67: 13-20. DOI: 10.1159/000434757.

Khan NH, Qian CJ, Perveen N. 2018. Phytochemical screening, antimicrobial and antioxidant activity determination of Citrus maxima peel. Pharm Pharmacol Intl J 6 (4): 279-285. DOI: 10.15406/ppij.2018.06.00187.

Ladaniya M. 2008. Citrus Fruit Biology, Technology and Evaluation. Elsivier Inc, Atlanta. DOI:10.1016/B978-012374130-1.50003-6

Makynen K, Jitsaardkul S, Tachasamran P, Sakai N, Puranachoti S, Nirojsinlapachai N, Chattapat V, Caengprasath N, Ngamukote S, Adisakwattana S. 2013. Cultivar variations in antioxidant and antihyperlipidemic properties of pummelo pulp (Citrus grandis [L.] Osbeck) in Thailand. Food Chem 139: 735-743. DOI: 10.1016/j.foodchem.2013.02.017.

Musyarofah N, Susanto S, Aziz SA, Suketi K, Dadang. 2020. The diversity of 'kristal' guava (Psidium guajava) fruit quality in response to different altitudes and cultural practices. Biodiversitas 21 (7): 33103316. DOI: $10.13057 /$ biodiv/d210755.

Na Nakorn S, Chalumpak C. 2016. Effect of tree age and fruit age on fruit development and fruit quality of pummelo var. Tabtimsiam. Int J Agric Technol 12 (3): 541-549.

Nandi P, Sekhar RS, Kundu S. 2019. Study on diversity of pummelo (Citrus grandis Osbeck.) based on core quantitative characters in West Bengal. Int J Curr Microbiol App Sci 8 (10): 1275-1283. DOI: 10.20546/ijcmas.2019.810.150.

Orwa C, Mutua A, Kindt R, Jamnadass R, Simons A. 2009. Agroforestree Database: A tree reference and selection guide version 4.0. http://www.worldagroforestry.org/af/treedb/

Overbeck V, Schmitz M, Blanke M. 2017. Non-destructive sensor-based prediction of maturity and optimum harvest date of sweet cherry fruit. Sensors 277 (17): 1-12. DOI:10.3390/s17020277.

Pichaiyongvongdee S, Haruenkit R. 2009. Comparative studies of limonin and naringin distribution in different parts of pummelo [Citrus grandis (L.) Osbeck] cultivars grown in Thailand. Kasetsart J. Nat Sci 43: 2836.

Preecha C, Na Nakorn S. 2018. Fruit growth and development of pummelo cv. tubtim siam at the difference tree age and fruit age for the optimal harvesting time under the climate variation. Int J Agric Technol 14 (7): 1685-1692 
Rahayu A. 2012. Characterization and Evaluation of Seeded and Seedless Indonesian Pummelo (Citrus maxima (Burm.) Merr.) Accessions. [Dissertation]. Institut Pertanian Bogor, Bogor. [Indonesian]

Sawant TP, Panchekar D. 2017. A brief review on recent advances of Citrus maxima (chakota). Intl J Recent Sci Res 8 (8): 19400-19416. DOI: 10.24327/ijrsr.2017.0808.0688.

Schlueter AK, Johnston CS. 2011. Vitamin C: Overview and Update. Evid Based Compl Altern Med 16 (1): 49-57. DOI: 10.1177/1533210110392951.

Sharma N, Sharma S, Niwas R. 2017. Thermal time and phenology of citrus in semi-arid conditions. J Pharmacog Phytochem 6 (5): 27-30.

Susanto S, Rahayu A, Sukma D, Dewi IS. 2011. Morphology and chemical characters 18 cultivars of pummelo (Citrus maxima (Burm.) Merr.) with seed and seedless. Jurnal Ilmu Pertanian Indonesia April 2011: 43-48. [Indonesian]

Susanto S, Rahayu A, Tyas KN. 2016. Indonesian Pummelo and their Ecophysiological Studies. IPB Press, Bogor (ID). [Indonesian]
Toh JJ, Khoo HE, Azrina A. 2013. Comparison of antioxidant properties of pummelo [Citrus grandis (L) Osbeck] varieties. Int Food Res J 20 (4): 1661-1668.

Tsai HL, Chang SKC, Chang SJ. 2007. Antioxidant content and free radical scavenging ability of fresh red pummelo [Citrus grandis (L.) Osbeck] juice and freeze-dried products. J Agric Food Chem 55: 2867-2872. DOI: $10.1021 /$ jf0633847

UNECE. 2017. UNECE Standard FFV-14 concerning the marketing and commercial quality control of citrus fruit 2017 Edition. United Nations, New York and Geneva.

Wangchu L, Tamut G, Singh B, Singh SR, Singh S. 2017. Studies on genetic variability of pummelo (Citrus grandis L.) in East Siang District of Arunachal Pradesh, India. Int J Basic Appl Biol 4 (2): 6473.

Wu SJ, Ng CC, Tzeng WS, Ho KC, Shyu YT. 2011. Functional antioxidant and tyrosinase inhibitory properties of extracts of Taiwanese pummelo (Citrus grandis Osbeck). Afr J Biotechnol 10 (39): 7668-7674. DOI: 10.5897/AJB11.721. 